\title{
THE CYCLICAL OVERPRODUCTION OF GRADUATES IN GERMANY IN THE NINETEENTH AND TWENTIETH CENTURIES*
}

\author{
Hartmut Titze
}

\begin{abstract}
Over the last two hundred years phases of overproduction and of scarcity in academic careers have recurred with a remarkable regularity. The cyclical development depends on the complex interaction between the varying determinants of growth and the varying conditions of social recruitment for specific careers. If professional prospects are favourable, careers will open up into educationally uncultivated strata, and if the prospects worsen, its recruitment basis closes a little further down again. The interplay of attracting effects (pull) and deterrence effects (push) produce the remarkable long-term pulsation of student streams in the vocational subject areas. German data from theology, law, medicine and higher education suggest that political control has effected little change in the cycle. Academic qualifications and limits on entry have always been introduced at the times of excess supply, and the history of structural change in German education is linked to these phases.
\end{abstract}

\section{Introduction}

The 'spectre of communism' which, according to the standard quotation of Marx, is roaming Europe, has a more quiet and refined relative, which for at least 150 years has periodically haunted the academic circles - the spectre of the 'graduate proletariat'. Its traces are less conspicuous, but can today be fairly reliably reconstructed with the modern means of electronic data processing. Phases of overproduction and scarcity in careers for graduates have recurred during the last 200 years with remarkable cyclical regularity. 'Policy' has had a relatively minor influence which has often been overestimated by contemporaries.

This contribution will first of all summarise the social mechanisms which underlie the observed fluctuations in the flows of recruitment to careers. Secondly, the periodic recurrence of excess supply and scarcity is sketched for the most important professional groups. In the third section some theses extracted from the analysis of the relationship between the internal dynamics of their development and the political control of careers will be discussed $^{1}$.

\section{Social mechanisms of academic status recruitment}

2.1 The double selectivity of pull and push. The complex interaction between the varying determinants of growth and the varying conditions of social

*An expanded German version of this article was published in Geschichte und Gesellschaft 10 (1984: 92-121) under the title 'Die zyklische Uberproduktion von Akademikern im 19. und 20. Jahrhundert'. This article was translated from the German by Elizabeth King. 
recruitment for specific careers are of fundamental importance for the longterm fluctuation of student flows and the cyclical status recruitment of graduates $^{2}$. If professional prospects are favourable careers will open up in their social recruitment basis a long way 'down' into educationally uncultivated strata. This pull effect may be determined, on the one hand, by an accelerated generational replacement in the career (a high replacement requirement because of the overaging of the profession), or, on the other, by an accelerated growth (a heavy expansion requirement due to job creation). If the two complexes of conditions coincide the effects will cumulate to create a particularly strong pull effect on the new professional generation. This effect attracts primarily those of the new generation who, because of their 'weak' social background (modest material resources, uncertain level of esteem) aim to grasp their relatively limited chances and will head particularly for those careers which offer rapid chances of rewards because of their scarcity situation.

If the generational replacement requirement of a career is 'satisfied' and the career prospects worsen, its recruitment basis closes a little further 'down' because the chances of entry are cut back in a stratified form from 'top' to 'bottom'. Two indicators register particularly sensitively in this context as the push effects is situations of overrecruitment are socially selective. The academics quota (i.e. the proportion of students whose fathers themselves have an academic education) constantly decreases during the periods of labour shortage in which the flow of students expands in a subjectspecific fashion, and continually increases during phases of overrecruitment in which the student flow diminishes. In particular those graduates who belong to the profession the children aspire to profit from discouragement as a mass phenomenon. By ousting potential rivals from the middle and lower strata, it becomes more probable for the junior members of privileged families to inherit the academic status of the father (quota of academic selfrecruitment).

A long-term fluctuation of the generational flows of new students in the vocational subject areas is produced through the social mechanisms of the double selectivity of academic status recruitment which, like a two-pole force field, interchangeably develops attracting effects (pull) and deterrence effects (push). Here the 'open' faculties or subjects, according to their basis of recruitment, are more strongly affected by cyclical fluctuations than the relatively 'exclusive' faculties or subject areas. This effect is diminished under the influence of favourable conditions of growth.

2.2 The influence of the internal dynamics of the age structure. Irregular processes of growth in a graduate career lead, as a rule, to a progressive age structure of members of a profession (heavily filled by the younger generation). Assuming that no countervailing influences are at work in the future this atypical distorted age structure of members of a profession will 
continually be transformed in a long-term wave movement from a progressive into a regressive age structure (heavily filled by the older generation). In the medium run in a profession there is periodic overaging and subsequently an accelerated generational departure and rejuvenation in the career (Burkhardt 1932).

The mechanisms of double selectivity are cyclically strengthened by this characteristic movement of the long-term age restructuring of members of a profession. The generational fate, the independent influences of the age structure, which in one instance expand and in the other narrow the chances of entry into the career, has as yet hardly been taken up as a theme in scientific research.

2.3 The flow equilibrium of careers. Through the interplay of all the individual mechanisms in a complex interaction of effects (Wirkungszusammenhang), careers are kept in a long-term flow equilibrium. Every individual career opens up for a while towards the bottom for educationally less cultivated strata (during periods of scarcity) and then more strongly closes off towards the bottom (during phases of excess supply). Since all careers are subject to this mechanism, but the relatively open ones more strongly so than the relatively exclusive, the social distances between the careers over the generations are retained. The internal flexibility of cyclical recruitment is capable of preventing, on the one hand, the modern functional elite of the graduate professions from isolating themselves in a castelike fashion and, on the other, helps to facilitate the fairly stable reproduction of the whole hierarchical structure of careers. The exclusive careers (law, medicine) remain comparatively exclusive and the open careers comparatively open (theology, teaching). Shifts of rank in the hierarchical spectrum of careers take place, if at all, only over the distance of several generations (for example, the enhancement of the status of dentistry between the Empire [Kaiserreich] until the period following the Second World War).

The idea of a flow equilibrium arises if one observes the complex interplay of mechanisms over a long period of time. The upcoming student streams do not fluctuate synchronically, but are displaced in time in a characteristic way. The periodic narrowing of chances of entry into one profession is as a rule associated with the 'still favourable' prospects or chances which are yet again cyclically expanded in other professional fields. This situation prevents any career over a longer period of time 'releasing itself' from the functional context, as the interest group of physicians has frequently tried to do (Hadrich 1931).

Since for educationally less cultivated strata the readiness to respond to situations of scarcity is greater than the inclination to be deterred in times of excess supply, more chances are redistributed during phases of scarcity than can be recovered during phases of excess supply. It is likely to be due to this 
factor that even exclusive careers lost part of their exclusiveness. Their dominant level of recruitment did indeed remain comparatively exclusive, but the range of strata from which they recruited their new generation became broader in the late nineteenth and twentieth centuries ${ }^{3}$. With this background in mind it becomes clear that during phases of scarcity there are particularly favourable conditions for accelerated processes of change. Subject-determined scarcity triggers an increased mobility for position-holders as well as for newcomers. By 'jumping' from one job to another the members of a profession move towards the top of the status system of a career. The 'worst' jobs remain unfilled through general promotion and have to be made more attractive by job enhancement. If there is a general under-supply of new recruits for careers (a deficit in holders of the university entrance qualification), then this process spreads over the whole hierarchical structure of careers with the consequence of a collective status elevation at the bottom end of the hierarchy ${ }^{4}$.

The highly stable recruitment basis of all careers in the long term is demonstrated in the social profile of university students (Figure 1). The mechanisms of double selectivity can be clearly discerned in the subject profile of middle and lower officials' student sons (Figure 2).

\section{Figure 1}

The Social Profile of Male German Students at Prussian Universities (1886/87-1932/33)

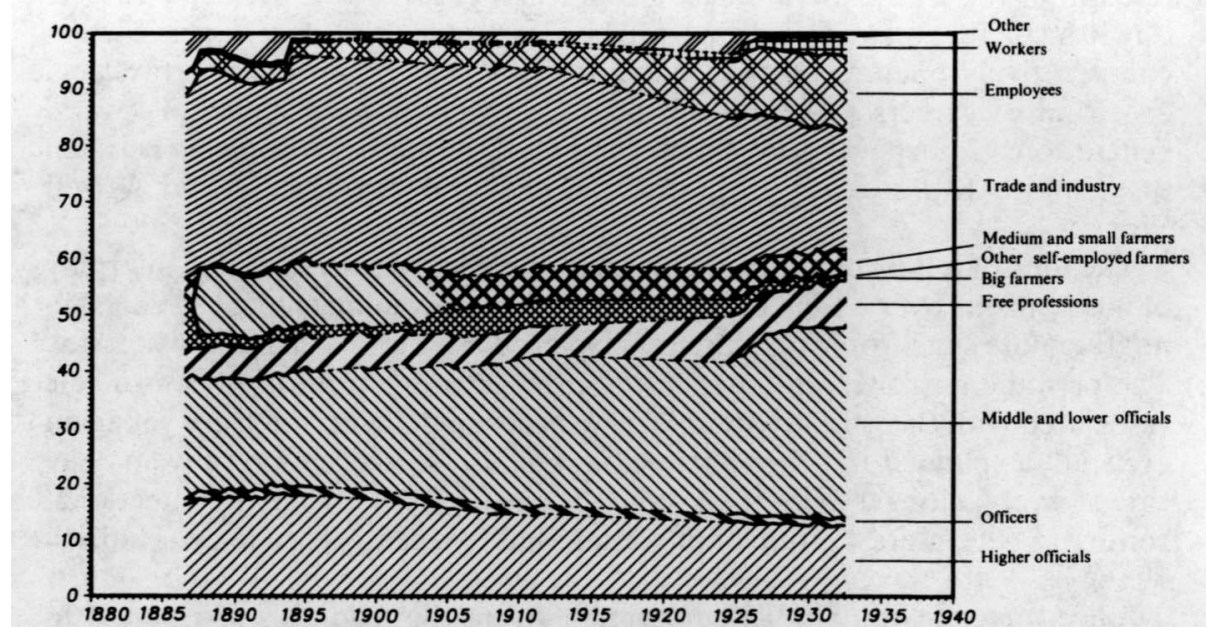


Figure 2

The Subject Profile of Male German Students at Prussian Universities by Social Origin: Middle and Lower Officials

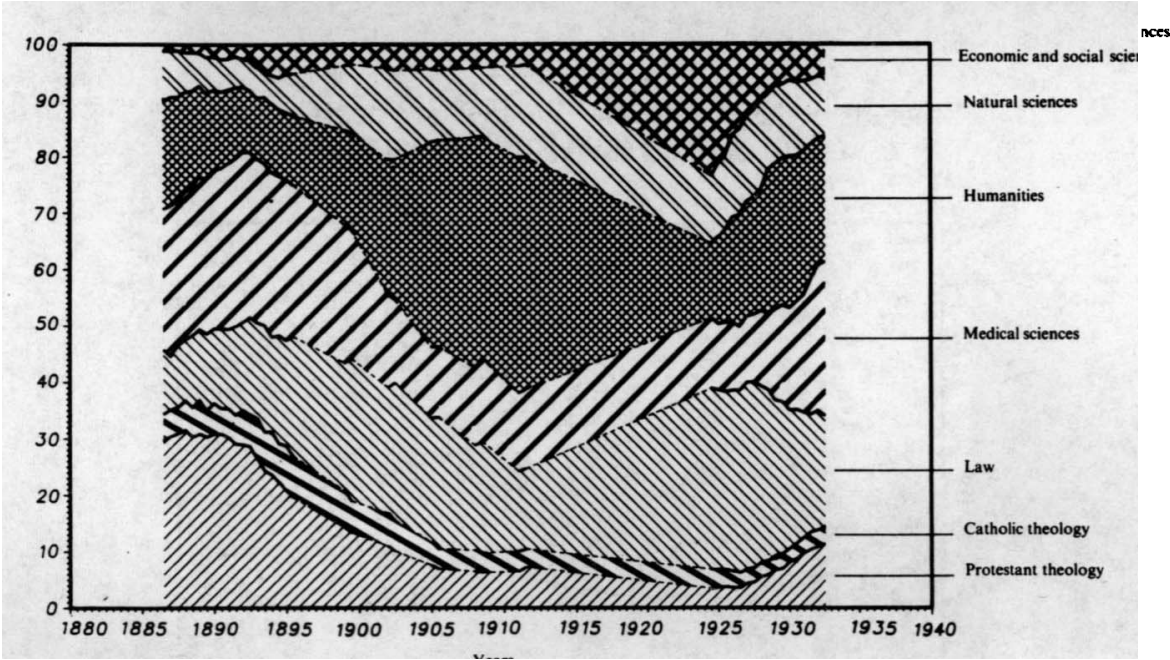

3. The periodic recurrence of excess supply and scarcity

With a complete wave movement it is possible to analytically distinguish four phases in which the probability of appointment varies. With 'below normal' entry to a profession, the deficit is initially increased even if the student numbers are already rising (scarcity build-up phase). It is only when the new generation which has completed its education rises beyond the normal requirement that the tendency is reversed (scarcity reduction phase). When the new generation which, at the point of equilibrium is still in education on oversubscribed courses, has become employable we arrive at the application barrier (excess supply build-up phase). It is only when the new generation which, because of the deterrence effects undertakes undersubscribed courses, has completed its educational training that the application barrier is no longer increased but begins to reduce again (excess supply reduction phase). At the end of this an equilibrium is yet again attained which, because of the enduring nature of these effects and the long 'production times' for graduates, ultimately again leads to a situation of scarcity. After these simplified considerations we can delimit the duration of a long wave: it will be at least twice as long as the length of the education for a career. An additional consideration is the number of years which can be estimated for the reduction phases of scarcity and excess supply. All the long waves identified during the period of investigation (1770-1945) in fact lie above this analytically delimitable minimum duration (of about 12 to 14 years). 
3.1 Protestant theologians. Between about 1770 and the Second World War we can establish a total of 6 cycles in student streams at the Protestant theological faculties of German universities. Figures 3 and 4 illustrate the long waves apart from the first one for old Prussian universities ${ }^{5}$.

\section{Figure 3}

Students in the Protestant Theological Faculties of the Old Prussian Universities (1820-1940)

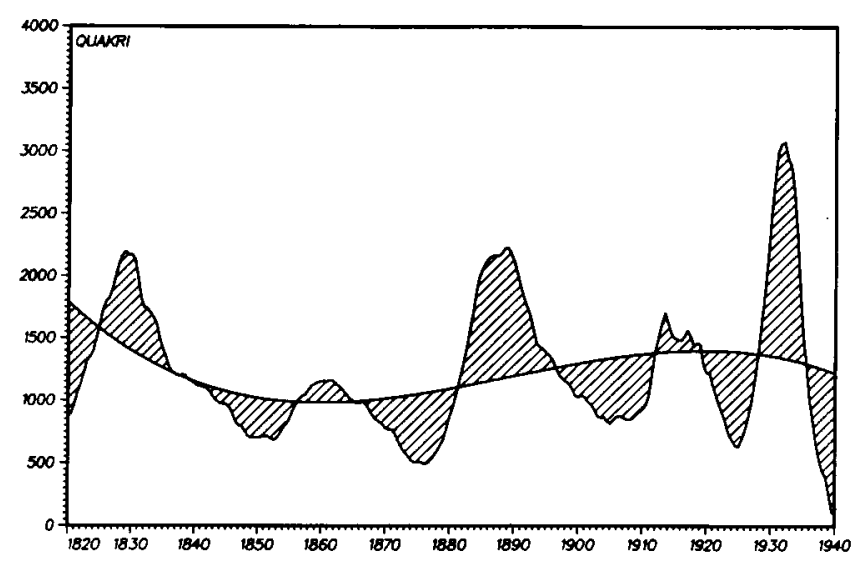

Figure 4

Cyclical Variations around the Trend (Relative Cycle Values) in the Numbers of Theological Students

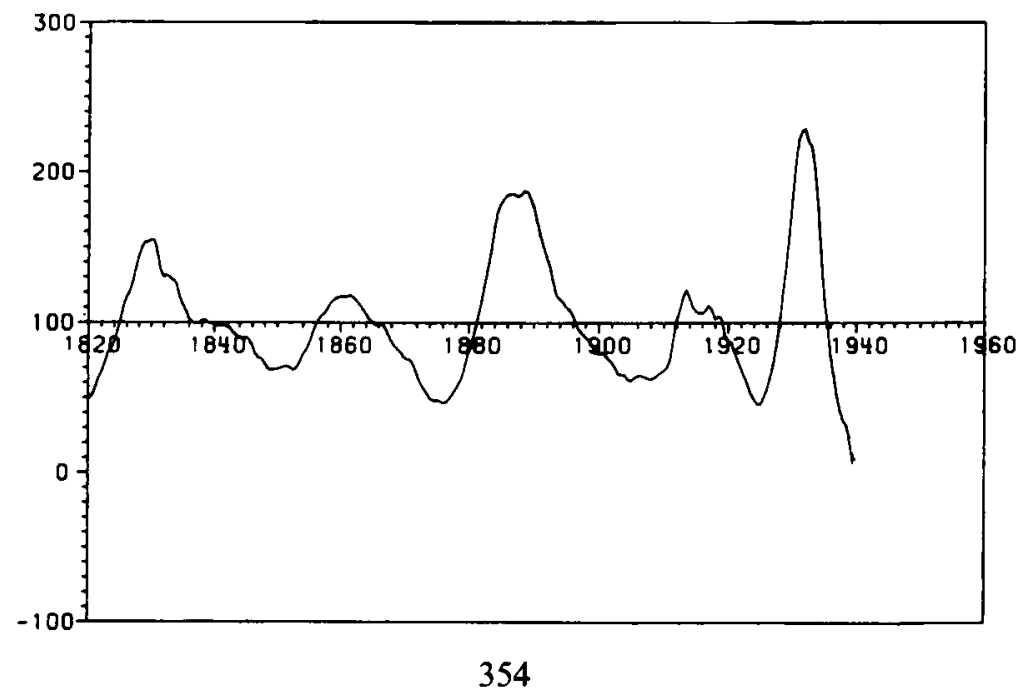


3.2 Students of law. Between the final third of the 18th century and the Second World War, a total of six cycles can be established with entry into legal careers (Figures 5 and 6 illustrate the long waves apart from the first one for old Prussian universities).

Figure 5

Students in the Law Faculties of the Old Prussian Universities (1820-1940)

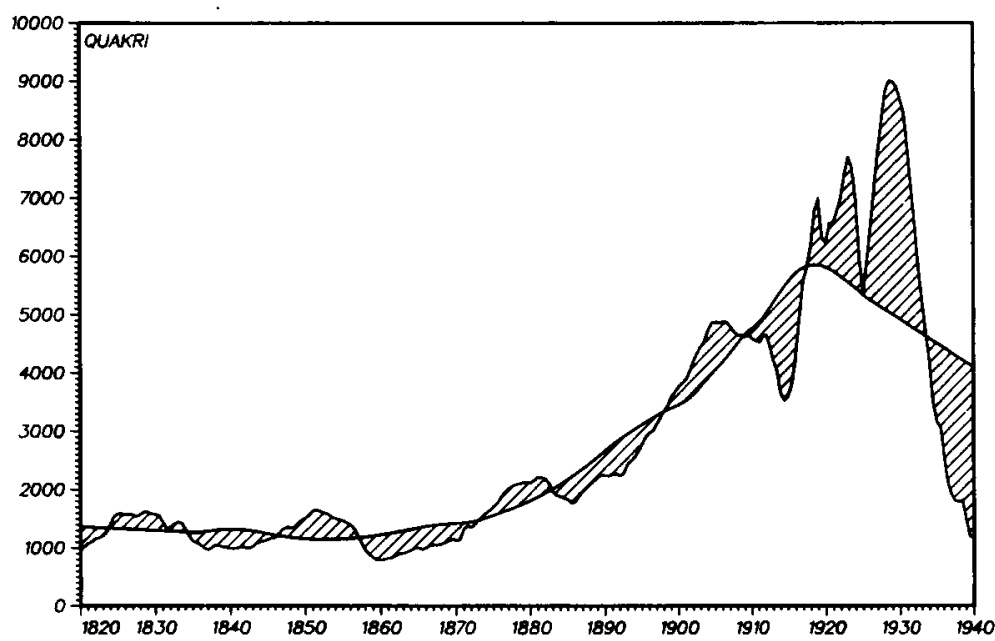

Figure 6

Cyclical Variations around the Trend (Relative Cycle Values) in the Number of Law Students

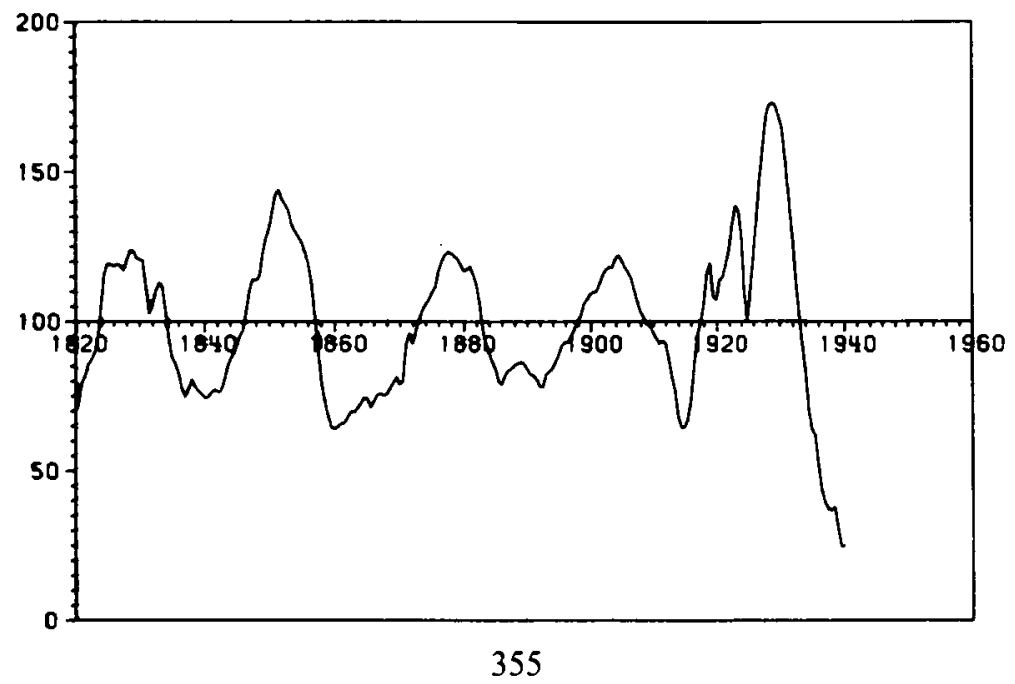


The findings regarding the first wave have hitherto had only a narrow empirical basis because of the unsatisfactory state of sources. A cycle of excess supply can clearly be distinguished for the widely renowned faculty of law at the University of Göttingen and the Electorate of Hanover (Ramdohr 1801; Gunkel 1911).

3.3 Students of medicine. We can find indications in contemporary discussion that even medical students were affected by the two waves of excess supply at the end of the 18th century and in the period from 1815 to the March revolution of 1848 . The available data, however, provide a hitherto too narrow basis for empirical analysis. Five waves can be registered for the medical streams at German universities between the period from 1815 to the March revolution of 1848 and the Second World War (Figures 7 and 8). In contrast to the other subject-specific student streams, the new generational stream had a relatively smooth flow until the foundation of the Reich. The phenomena of excess supply in the 18th and early 19th centuries should have appeared only in heavily condensed regions (if at all) because of the unequal distribution of doctors in town and country (Conrad 1884:120; Hoffmann $1843: 210 \mathrm{ff}$.).

\section{Figure 7}

Medical Students in the German Universities (1830-1940)

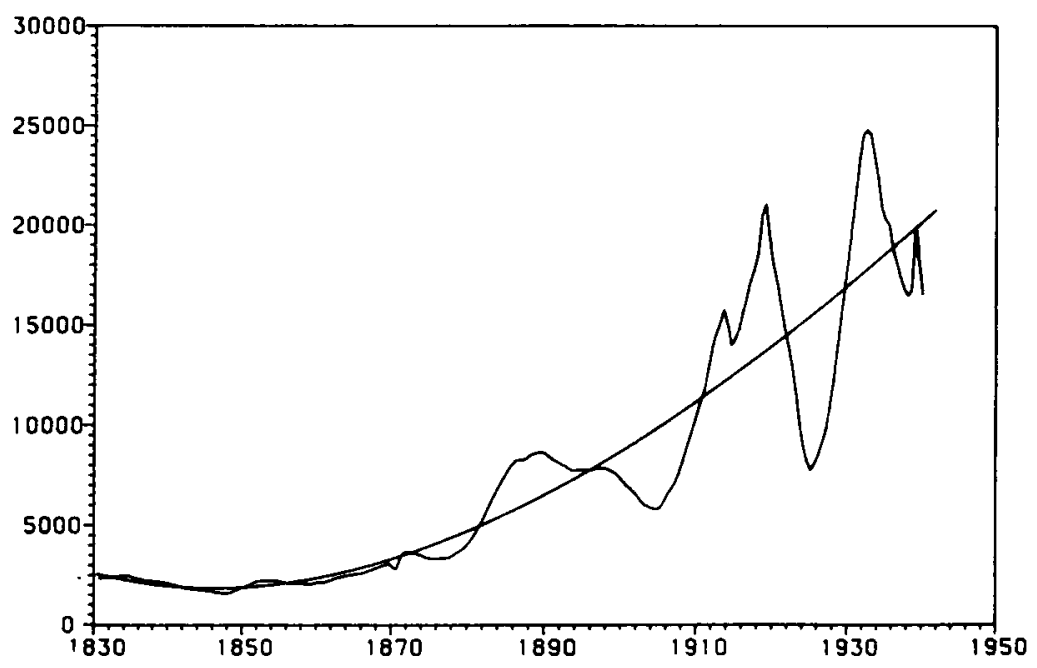




\section{Figure 8}

\section{Cyclical Variations around the Trend (Relative Cycle Values) in the Numbers of Medical Students}

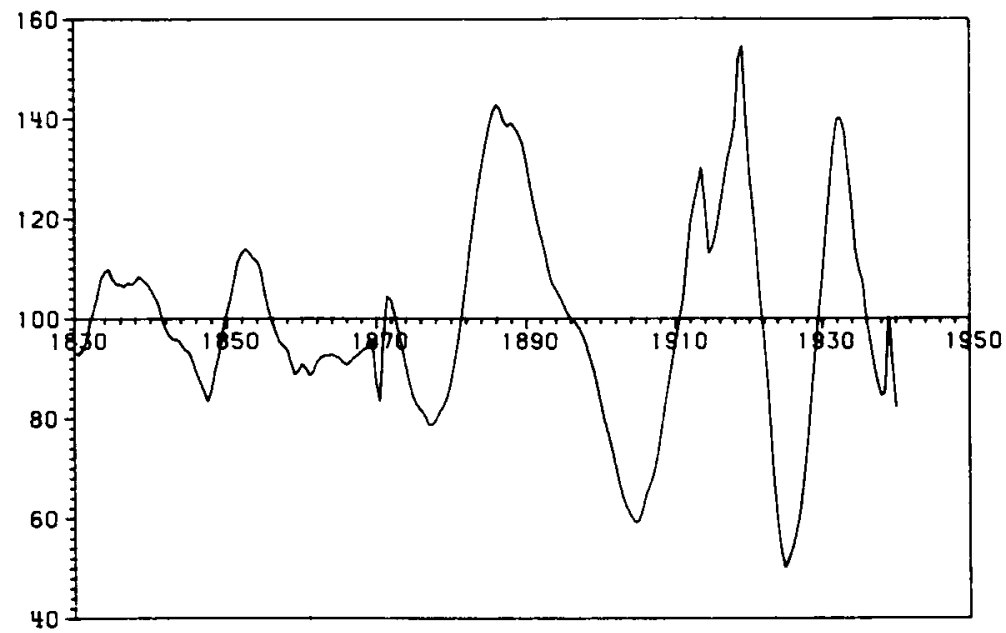

3.4 Teachers in higher education. We can establish four phases in which situations of scarcity and excess supply were cyclically reproduced with regular recurrence from the beginning of the 19th century up to the present:

1. During the first decade of the 19th century, in which higher education was reorganised, there was at first a scarcity of teachers with an academic educational background. This scarcity then turned into excess supply during the first half of the 1830s, which lasted until about the middle of the century (Titze 1981b).

2. During the 1860 s and 1870 s, which marked the beginning of the modern growth of education with a historically new secular trend, an appreciable scarcity of teachers yet again predominated. Signs of excess supply were again indicated from the early 1880 s until the turn of the century, which was further exacerbated by a restrictive educational policy (Herrlitz and Titze 1976; Herrmann 1977) ${ }^{6}$.

3. During the first decade of this century the professional prospects in higher education were particularly favourable because the cyclically occurring scarcity was further exacerbated through an enormous growth in education. The first signs of a renewed wave of excess supply were noticeable on the eve of 
the First World War. The career was again oversubscribed during the whole of the inter-war period. During the second half of the 1920 s there were temporary subject-specific bottlenecks in the supply of teachers to higher education without significantly improving the general prospects in the career (Nath 1981; Zymek 1981).

4. Due to the drastic interventions in teachers' studies in the thirties, a longterm phase of scarcity was cyclically preprogrammed for the period after the Second World War, which was initially concealed because of the multifarious consequences of the war (influx of expellees and refugees). There was a considerable under-supply from the 1950s until the mid-seventies. Due to the unprecedented growth of education since the mid-sixties, the phase of scarcity with favourable professional prospects extended as long as it did a hundred years ago when higher education also had to be expanded under pressure of modernisation (Kramer 1964; Hillig 1964; Schmidt 1982).

Looking at the problem in the long run in comparison with the other careers, two structural characteristics have to be emphasised. The worldly teaching profession, like the clerical office, is socially a relatively open career. However, because of the secular growth of education since the final third of the 19th century, teaching in higher education, unlike the clerical office, is a modern growth career. Cyclically appearing situations of scarcity and excess supply are reproduced in a particularly dramatic fashion due to the cumulative effects of these two complex conditions for specific patterns of recruitment (openness and growth). While the crisis of excess supply during the period from 1815 to the March revolution of 1848 found its clearest expression with theologians, it was the philologists who were most affected during the Empire (Kaiserreich) as well as the inter-war years?

\section{The internal dynamics and political control of careers}

These outlines of the cyclical reproduction of status demonstrate that the complex processes of the periodic recurrence of excess supply and scarcity are determined by a remarkably independent dynamic. Over approximately 175 years the waves pulsated like high and low tides over succeeding generations without their structure up to now displaying any 'processes of learning'. This persistent 'non-learning' poses the question of the political controllability of the processes under investigation. Here it is obvious that this question cannot be conclusively answered even after several years of research.

Up to now no systematic consideration has been given in research into the social history of education to the fact that the most important acts of reform in the reorganisation of higher education, which have marked the path of development of the modern system of qualifications since the 18th century, have been carried through precisely during the phases in which the cyclically forever recurring problem of excess supply has called for measures of 
adaptation and led to structural changes in the education system. The observation of this connection should open up new and deeper insights into the function and structure of the modern German education system.

4.1 The institutionalisation of educational selection. At the high point of our first wave of excess supply the university entrance qualification (Abitur) was for the first time introduced in Prussia in 1788. In the 1820s and 1830s several other German states followed the Prussian example when a generation later the second cyclical wave approached and also introduced the university entrance qualification as a precondition for entry to academic studies and careers (notably, Baden between 1823 and 1836; Bavaria and Hessen in 1824; Brunswick in 1826; Oldenbourg between 1827 and 1830; Saxony and Hanover in 1829). In Prussia the preconditions for admission to academic studies were tightened and universally enforced through the regulation of 4 June 1834 (Herrlitz 1973; Romberg 1979; Jeismann 1974).

The first signs of a modern bureaucratic rationalisation of entry to graduate careers can be interpreted as a political reaction to the new problem situation which was provoked by the liberalisation of the chances of entry. After the abolition of restrictions according to status at birth of the right to study, which could no longer be regarded as legitimate in the first decades of the 19th century, the recruitment basis of careers expanded to encompass the middle and lower social strata. Due to this the already effective trend of pull into graduate careers, which was cyclically preprogrammed through the situation of scarcity, was additionally increased after the wars of liberation and particularly in the early twenties. Different front lines of defence against the increasing status competition resulted from each social interest situation. While the battle for chances of entry to the legal careers in the service of the state erupted between the dominant aristocracy and the bourgeois graduate elite, the front line of the battle for the much less prestigious and remunerative clerical offices was carried out between the middle and 'lower' classes. Modern structures crystallised under this pressure for rationalisation. The reorganised education system during the crisis of excess supply in the period from 1815 to the March revolution of 1848 gained independent importance as a system of selection. The grading of chances of entry according to publicly recognised 'marks' replaced the graded privileges and diminished rights (preferential chances and exclusion from careers according to criteria of birth). Educational selection generated graded qualifications for social participation as an ordering schema for modern social differentiation ${ }^{8}$.

In contrast to the traditional forms of 'natural' selection according to 'background', the bureaucratically rationalised control of entry by 'educational selection' displayed structural superiority in a dual fashion. It was possible to decide more independently about the entry to or exclusion from a career in the reorganised system of educational rights (at least the formal entitlement of 'without consideration for the status of the person'). The new system of selection oriented to universalistic criteria facilitated: 
1) that potential applicants could be excluded definitively at an early stage, since the entry to 'further' education and the graduate professions were linked; 2) that those who were rejected accepted their exclusion was justified because only the formally equal treatment of all made it possible for negative selection to be as equally taken-for-granted as success in higher schooling and universities.

A year prior to the introduction of the university entrance qualification in the Kingdom of Hanover an anonymous critic of the existing system of instruction summed up in a classical fashion the strategic importance and superiority of the new humanistically reformed organisation of education in the words: 'Should the members of the lower classes not be embittered against the state if they are openly told that your road to honourable positions is closed even if you achieve what higher-standing people cannot achieve? Members of the lower classes in suitable schools are just being given the chance to understand that special talents are needed for every art and every trade' (1828). If there it is the second front line of defence against status competition from 'below' which manifests itself, Robert Mohl (1845 : 271) seemed rather to have the first front line of the offensive fight against the aristocratic privileges of office in mind when, in the forties, he praised the 'democratic nature of examinations': 'This inconspicuous institution has in most German states contributed more to the elevation of the educated middle classes and to the state's removal of the arrogant and useless aristocrats by birth than all constitutions and revolutions'. Even the offspring of the most distinguished family would be forced, through the examination system of education, 'to gain at least the minimum of essential knowledge. Without it he cannot take the first step, and thus no other that follows from there'. 'Because of it the rules of strict examinations are as popular with the middle classes as they are hateful to a section of the aristocracy ... Therein lies the feeling of a social transformation and the loss of great privileges' (Mohl 1841:84 f.) ${ }^{9}$.

4.2 State control of the new generation of graduates. A forward-looking new system of recruiting the rising generation crystallised out of the legitimate linking of educational selection with professional graduate careers after the removal of restrictions imposed by status at birth. But with the concrete social conditions of its developmental phase it initially had a stabilising effect on the mobilised society.

The modernised system of higher education during the period from 1815 to the March revolution of 1848 could, to a far-reaching extent, still be controlled to conform with interests under the social control of the high-handed bureaucracy and used for the retention of privileged chances of reproduction by the educated civil and clerical servants. Disquieted by the rush with which the sons of the 'lower classes' inundated the grammar schools (Gymnasien) and universities in the twenties, the education authorities adhered to a strictly bureaucratic regimentation of courses. The highest priority determining educational policy until the late 1850 s was to control higher education by the 
narrow 'criteria of demand' and to conserve the structure of societal privileges with the aid of a rigidly upheld policy of entitlement. The restriction placed on the supply of education, which can be inferred from the grammar schools which were newly authorised after the wave of excess supply and the quantitative development of school-leavers with the university entrance qualification, are in this context the most important indicators of the restrictive control on the 'demand for education'. Only 7 further full grammar school establishments were added to the existing number in the whole Prussian state in the two decades between 1832 and 1852 during which the population grew considerably. The number of school-leavers with the university entrance qualification, which had increased in the decade of 1820 to 1829 to a level of over 15,200 (the sum total for the complete 10 years) was, in the thirties, reduced to a level of 13,500 and sank further in the forties to around 12,000. It was only after these two decades of educational cut-backs that the level of the 1820 s was reattained and exceeded in the fifties. The indicator of 'students per 100,000 inhabitants' points in the same direction in the development of university attendance figures. After the rapid growth in the first third of the 19 th century ( 54.8 students per 100,000 inhabitants in the years 1826-1830), the relative figure of university attendance in the second third of the century was determined by contraction and stagnation ( 34.9 in 1855-56). It was only from the mid-1870s that the rate increased heavily and it was only at the beginning of the eighties that the level once attained as early as $1830(1885-86$ $=57.7$ students per 100,000 inhabitants) was yet again exceeded.

In their restrictive control over demand, the education authorities had a broad spectrum of interventions at their disposal, which extended from relatively 'soft' to 'harsh' measures (warnings prior to study, personal admonition by teachers and heads of grammar schools, written exhortations to parents, control through grant awards, the tightening of the examination system, a rise in fees and cut-backs in the 'entitlement' to higher education). The bureaucratic means of control all aimed at a 'cooling out' of the hopes for the future and expectations of status of the lower/middle classes who had begun to discover a channel of promotion for their sons in the extended education system. The diverse mechanisms of discouragement made people subtly aware of the discrepancy between superior graduate professional goals and the available material resources; they made them conscious of the hopelessness of educational striving and dampened the lower classes' hopes for promotion ${ }^{10}$. In fact the 'voluntary' retreat from status competition by 'self-selection' striven for in educational policy led to the same outcome as the enforced exclusion by means of special legal restrictions in the 18th century. The new system of recruitment evidently permitted the upper classes to retain their preferential chances without arousing the suspicion of arbitrary privileges among the lower classes. After a detailed listing of the social background of the candidates for clerical examinations, the Göttingen Professor of Theology, Pott (1830), reported to the Hanoverian Konsistorium: 'The implicit observation of this survey is that even if only the sons from the 
intellectual and educated classes chose the study of theology, there would still be no shortage of candidates for clerical office, especially since the university entrance examination prevents all caste spirit (Kastengeist), and there would still be some other, more than extraordinarily promising, subjects for the clerical classes'. Due to the interest-oriented control inherent in the new system of academic status selection, the implicit criteria of selection and promotion very frequently were still based on social background at birth and not the personal qualification by education. This hard truth should not have escaped particularly the brightest of the lower classes during the crisis of excess supply in the period before the March revolution of 1848. In the face of the sombre prospects for entrance into the office of their choice, there was a temptation to keep quiet about the discriminating background or to 'correct' it in line with expectations. Seven years after the introduction of the tightened 'achievement by selection', the Hanoverian Konsistorium decreed on 19.4.1836 that the candidates would in future have to present a "birth certificate' on registration for the examination, so that 'no doubts and reservations' about their social origins (!) would arise, 'as had happened in some cases in the past'.

\subsection{The independent expansion of the education system under the pressure of} modernisation. The unintended delayed consequences of the decades of entitlement policy caught up with the education authorities from the 1860 s. Manifestations of scarcity were shown in all careers which could again be overcome only in the long term and gradually because of the long 'production times' of graduates. Under the pressure of modernisation the capacities for the training of the new graduate generation (full-time grammar school establishments, university chairs) had to be expanded rapidly to catch up with demand, which had been blocked since 1830. Seen from a long-term perspective, the first growth push (between approximately 1860 and 1880) does not appear anywhere as dramatic as the more recent investigations into the problem of excess supply lead us to expect. The necessary and rapid independent expansion of the education system essentially represented a successful achievement of adaptation to the increasing demand for students with the university entrance qualification and for graduates. The ascertainable 'overproduction' on the graduate labour market could relatively unproblematically be integrated due to the favourable conditions of growth up to the First World War. The second growth push beginning just before the turn of the century, in contrast, developed to a much greater extent an independent (up-front) growth, which was ahead of traditional social needs. In the sense of a general leading function, this second push in the growth of education exerted up to the mid-1930s a disproportionate pressure on the labour market of graduates and triggered off the much-cited 'intellectual currency crisis' (Lundgreen 1981; Kaelble 1976). The instructive eighties and nineties in educational policy lie between the two characteristic phases of growth push in which the authorised higher education removed itself from traditional state control and political direction. 
After the early eighties the educational authorities were under the spell of the problem of excess supply and the much-discussed danger of the emergence of a 'graduate proletariat' exercised a not inconsiderable influence over Prussian educational policy. In the tradition of the bureaucratic control of the 'demand for education' in the period before the March revolution of 1848 , the government yet again attempted to control the periodically reappearing problem of excess supply by means of an ingenious policy of entitlement. Empirical analyses of the long-term development of student flows lead us to conclude that the state control of the new graduate generation during the Empire was no longer successful.

Just how limited the scope for action for political counter-controls was was brought into consciousness by a memorandum of 31.3 .1890 about the problem of the graduate proletariat, in which Friedrich Althoff and Arnold Sachse summed up the strategic considerations within the administration and responded matter-of-factly to a Bismarck initiative. Polite in formulation, courageously sober in substance, the expert ministerial civil servants made it clear to the Reich Chancellor and the Minister of Education and the Arts, von Gossler, that the suggested measures against the 'overproduction of graduates' were not any longer enforceable and were highly questionable in their effects on both social and educational policy. The abolition of the deferment of payment of honoraria for lectures (which enabled poor students to raise their student fees) would meet with serious legal reservations, because here it was a question of intervention in the official professorial income, "which cannot be enforced without their agreement other than by legal means'. Even the 'simple abolition' of the deferment of payment, as recommended by the Reich Chancellor, 'is not possible except by deterring both the unwanted elements and numerous well-suited young men from university studies. This is a matter of ensuring that the baby is not thrown out with the bath water'. The planned grant reform (concentration of assistance on a few students) was 'opposed' by the surveyed universities with the 'reservation that legal means would be required for a radical remedy, since we are here frequently dealing with established trust arrangements, particularly in the case of family foundations, vested rights or legal reversions'. 'Only with the greatest reluctance should one set to work' with the intended increase in student fees, too. An excessively high increase 'would not be copied' by the other German state governments 'and hence undoubtedly lead to the situation that Prussian universities would be less well attended, thus be harmed in the quality of their teaching profession and therefore suffer losses in the ascendancy which they currently enjoy'. The hint by the Reich Chancellor that the measures in mind are much more easily carried out, since they deal with simple ministerial instructions, 'scarcely applied to university establishments. Because these were in the main based not on ministerial instructions but on statutory arrangements and, in part, even on civil law, which could only by law be altered without the agreement of participants. Just from the formal point of view, therefore, with all these things it is recommended to keep in mind the proverb 'look before you leap' '. 
It is quite obvious that legislation was precisely what the administration wanted to avoid. The intended fiscal measures to keep at bay unwelcome status competitors were awkward as the object of public parliamentary discussion. The road taken since the reorganisation of institutions of higher education in the first decades of the 19th century, to link universalistic criteria of selection with the entry to graduate careers (at least according to formal claim), could in the last decades of the 19th century even by the word of the ruler Bismarck no longer be deflected into a plutocratically oriented direction which would make it patently obvious that study places and student grants were again to be reserved for a wealthy minority ${ }^{11}$. The Senate of Leipzig University, which was asked to comment, clearly formulated its misgivings: 'It would be neither in the spirit of German universities nor the intention of its noble founders to make scientific study appear to be the preferential prerogative of the wealthy and to prevent the less wealthy but hard-working and intellectually able from studying'.

As the development in the last two decades of the 19th century demonstrated, the administration did not have the political resource of action, 'power', at its disposal to facilitate the resolution of the structural problem in accordance with the traditional model (cut-backs in the supply of education) ${ }^{12}$. Secondly, even the basis of information for political action was too weak to bring the cyclically recurring problem of excess supply, now under the conditions of growth, under control. The analysis of demand, undertaken on the order of the Prussian Minister of Education and the Arts in 1889 by the Göttingen political scientist, Lexis, could provide only preliminary findings because of 'the sketchiness and unreliability of the sources used', as Althoff and Sachse acknowledged in their memorandum. Even the comprehensively worked out second version of the memorandum about the normal demand for students, into which critical responses on the demand side about the specific need for university graduates were entered, could in no way 'shed clear light on the matter', for which the administration had hoped. Independent critics could convincingly demonstrate that 'the bases of calculation are largely inappropriate'. The Görlitz grammar-school teacher, Bünger (1893:60), astutely argued that the result of the needs analysis was particularly questionable 'since the memorandum in fact does not calculate Prussia's need for student manpower but seeks to establish how many persons can annually gain comfortable posts' 13 . It was only at the turn of the century, when the prospects for graduate careers were again improved, that even within the administrative circles the insight asserted itself that the continuing growth of higher education could no longer be halted by (traditionally conceived) counter-measures, but could at best be channelled by a pragmatic policy of reform.

4.4 The crisis of the academic qualifications system. The second growth-push since the turn of the century and the interaction of numerous structural changes burdened the graduate labour market in the inter-war years with 
almost irresolvable problems. Even if we consider the special causes of growth (such as the academisation of new professions and women's admission to studies), the decisive age classes for candidatures to graduate professions were roughly twice as heavily occupied between 1929 and 1933 as the average of the years between 1910 and 1914. If the higher schools in the German Reich had approximately 16,000 school-leavers with the university entrance qualification in 1910, the figure was already around 30,000 in 1928 , only to rise in the years up to 1933 to the level of 40,000 , until the effects of the lower birth-rate during the world war led in the subsequent years to a noticeable relaxation at universities and on the labour market. The situation was aggravated particularly because the career of elementary school teachers was practically closed from the mid-1920s due to excessive overproduction and the elimination of traditional teachers' training college establishments. Thus an important channel of promotion was blocked for years below the level of graduate careers. What this restructuring meant can be guessed if we keep in mind that, in normal circumstances, the career of the elementary school teacher alone absorbed as many as roughly half the candidates as all of the established careers supplied by university study put together.

In the face of the growing student masses graduates felt threatened by an 'intellectual currency crisis', which can be understood in the light of a simple calculation. In 1931 the number of all candidates for graduate professional positions amounted roughly to 150,000 persons. The number of people employed in graduate occupations in Germany fluctuated between approximately 300,000 and 350,000 , so that one candidate who was currently in education stood behind almost every second graduate. The total annual replacement requirement was calculated at about 10,000. Depending on the various estimated rates of wastage in students who 'failed' in their studies, there was in contrast an expected annual number of graduates two to three times that number. As early as 1932 one had to reckon with a 'minimum of 4045,000 young graduates who are currently seen as surplus to requirement' (Schairer 1932: 34). The Breslau General Superintendent Zänker, made the point in 1933 that if all current students were to find their place in the professional labour market, then it would be necessary to have around one million professional positions instead of the existing 330,000 (Achner 1931; Sikorski 1932; Zänker 1933).

Administrative problem-processing, which was concentrated in the hands of the Prussian Ministry for Science, Art and National Education and the Reich Ministry of the Interior, strove for long-term oriented strategies of action, which in principle were supposed to come closer to solving the problem of excess supply which was recurring in an ever exacerbated fashion. Apart from the systematic extension of academic study and career counselling, the Prussian Ministry sought particularly to improve the basis of information for political control. This came about, on the one hand, through the reorganisation of the 'Statistics of German Universities', the extension of which was supposed to offer a secure basis for the forecasting of the supply of graduates. 
On the other hand, the "National Economic Centre for Higher Educational Studies and the Graduate Professional System' was established in Kiel with the aim of penetrating the chronic chaos on the graduate job market by means of scientific analysis. The problem Lexis had tried to resolve for the Prussian educational authority in 1889 during the days of the Empire, the Kiel Centre was now supposed to look into with increased expenditure and on a more solid basis, in order to hopefully counteract the overproduction of graduates with scientifically informed strategies for action. In the Reich Ministry of the Interior, the considerations revolved more around the question of principle which possibilities of change in the entitlement system could block and channel the mass movement into academic studies. Even with this definition of the problem, the political actors in the Weimar Republic were continuing a tradition of the Empire, in which similar strategies of rechannelling had already been developed for the control of excess supply. The steadily renewed attempt made between 1880 and 1930 to establish an attractive intermediate structure in the organisation of schools, which was meant to 'absorb' at least a part of the 'unhealthy' influx into the advanced levels of the higher schools, however, proved a difficult undertaking in which the hoped-for successes were not achieved.

Differently from the civil servants in the cultural departments of Wilhelmine Germany who high-handedly overestimated their scope for action for a while in the eighties and nineties, their successors in the Weimar Republic were more self-critical in their assessment of the limited means of control at their disposal. On the occasion of the spring 1929 budget discussions in parliament (Landtag), the Prussian Minister of Education and the Arts, Becker, gave expression to the powerlessness of the administration, which had in the inter-war years more and more apparently become the prisoner of precisely that system of entitlement, the establishment and enforcement of which it had promoted in the 19th century: 'That we have by our own actions landed ourselves in the middle of these problems proves that the whole problem of entitlement can definitely not be resolved by the instructions of the Education Minister, but only through a hopeful and gradual recovery of the economic strength of our people and, until we have achieved this, by selfreflection of the large professional associations in cooperation with a strong Reich government' (Zymek $1982: 226$ f.). The educational administration was overcome in its long-term intentions of planning and control by the pressure to act with unavoidable immediate measures in response to the worsening of the problem of excess supply in the early thirties. There was no longer any question of planned initiative for a forward-looking regulation of the new generational flows in graduate careers, since policy was exhausted by the short-term constraints and all action revolved around the single question of how the respective next heavy school-leaving year with the university entrance qualification could be deterred from entering higher education and accommodated in other areas. 
With this background in mind it becomes clear that the extraordinarily favourable conditions of growth for graduate careers during the Empire meant an unsuspected mortgage for the inter-war years: the horizon of expectations both for the traditionally educated bourgeoisie and the middle classes who were interested in promotion was geared to further growth, particularly since the latter took and consciously wanted to take upon themselves enorn uns efforts and consumer sacrifices to facilitate their educationally motivated childrens' absorption into the societal privilege structure through the attainment of qualifications. While the education system in an uninterrupted dynamic released continually broader streams of candidates onto the graduate labour market, careers grew only at a much slower rate than in the pre-war period and at the same time took on only a modest number of additional applicants on top of the normal replacement requirement. The General Secretary of the Kiel Centre decided that 'the tragedy of the situation resides precisely in these enormous differences in speed' (Keiser 1932: 1591) ${ }^{14}$. The specifically German system of qualifications and the rigid entitlement thinking to which it gave rise represented a burden for the whole political system in this crisis situation, which was not to be underestimated, when there was hardly any 'growth' to distribute. The bureaucratic control mechanisms over the system of qualifications, which allocate the new generation via educational careers to the status hierarchies of the employment system, develop high capacity for social integration so long as propertied groups are left untouched and social climbers can be integrated with relatively little conflict into the structure of privileges through growth because no-one has anything to lose by it. From this aspect, the hysteria about excess supply during the Empire to a large extent remained mere ideology, purposeful propaganda for deterrence and discipline. During the crisis of excess supply at the end of the Weimar Republic the intensified status competition now put a squeeze on, from the bottom to the top and from there back to the bottom by processes of repression because there was hardly any growth to be distributed, but instead propertied groups were under attack. The control mechanisms of the system of qualifications were weakened in their integration capacities because one of their fundamental conditions, namely the growth of careers, was no longer adequately fulfilled. 'The professional pyramid has begun to totter because the surge for the top undermines the foundations and makes it incapable to withstand the high pressure from the top. And the peak itself, the most fragile part of the structure and the one most exposed to the elements, crumbles and cracks with its tensions' (Niessen $1931: 16)^{15}$.

The National Socialists exploited the 'intellectual currency crisis' of graduates and added to the many-layered projected images with which those strata who were threatened in their privileged status-maintenance or disappointed in their hopes for promotion defended themselves in their fear of social downgrading. The brutally restrictive measures of the early years of the Third Reich with which the Nazis sought to eliminate the problem of the 
'graduate proletariat', ended even more in a cul-de-sac, as the more far-sighted experts in the authorities, industry, science and professional associations were bound to point out soberly a few years before the beginning of the war. The general scarcity of highly qualified new generational manpower, which in certain sectors had already started and was forecast for the 1940s and 1950s, attained such devastating proportions that under the pressure of this problem corrections in the course of restrictive educational policy were made unavoidable. The long-term effects of the internal dynamics of the waves of recruitment to graduate careers were in any case negatively intensified to such an extent in the 12 years of the 'Thousand-Year Reich' by misguided political attempts of control, that in the decades after the Second World War there was an enormous need to catch up, the full extent of which remained concealed by the, in this respect, favourable influence of the consequences of war (the influx of expellees, the immigration of highly qualified specialists from the GDR). Under pressure of the more pronounced emerging lack of supply (general deficit in school-leavers with the university entrance qualification) a more rapid expansion of the education system was again enforced in the 1960s and 1970s, which should be accorded a similar ranking in the long-term historical perspective as the adaptation of the education system during the first push for industrialisation between 1860 and 1880 .

\section{Notes}

This contribution summarises further findings of the DFG-Project QUAKRI ('Qualification Crises and the Structural Change in the Education System'), in which, apart from the Göttingen Research Group (directed by H.-G. Herrlitz and H. Titze), another group at the University of Bochum (directed by D.K. Müller and B. Zymek) as well as P. Lundgreen (Bielefeld) participated. The comprehensive statistical data ascertained by QUAKRI are due to be published in a Datenhandbuch zur deutschen Bildungsgeschichte (Data Handbook on the German History of Education), parts of which relating to higher education (Project Group Bochum) and the university system (Project Group Göttingen), were published in 1987. In this version education statistics are published which could not be incorporated here due to space considerations.

2 The following general explanation is based on the differential empirical analysis of the two million pieces of data, which have in the meanwhile been processed and recorded by the Göttingen group over the last six years. The social mechanisms are presented in more detailed form in Titze (1981) and recently in Titze et al (1985).

3 Regarding the state of research, cf. Jarausch's (1982) standard investigation. For a summary with international comparisons, see Kaelble (1983).

4 The thesis is based on the analysis of the long-term development of change in office within the Protestant Church of the Old Prussian Union (Troschke 1931). During phases of excess supply there is, in contrast, hardly any mobility in the status system. The incomes of clerics and teachers were increased mostly during phases of scarcity.

5 In Diagrams 3 to 8 the respective semester-resolved subject-specific student streams are at the outset presented in the development of their absolute frequencies. The trend figures outlined in this represent the 'optimal' adaptations according to our present state of research. In each second diagram the cyclical fluctuations around the trend of actual interest to us are presented as a time series of relative cycle values. These values indicate how far a cyclical upturn exceeds the 'normal' level of the general trend in percentage deviation and a downturn takes place below it. The cycle values fluctuating around 100 make the fluctuations of student streams apparent in their 'pure' form, as it were. 


\section{THE CYCLICAL OVERPRODUCTION OF GRADUATES IN GERMANY}

\section{References: Books and Articles}

ACHNER, L. 1931. 'Der Arbeitsmarkt der geistigen Berufe' (The Employment Market for Intellectual Professions), Allgemeines Statistisches Archiv $21: 481-95$.

BÜNGER, R. 1893. 'Der Bedarf Preussens an Abiturienten' (The Prussian Demand of SchoolLeavers with the University Entrance Qualification). Preussische Jahrbücher : 52-84.

BURKHARDT, F. 1932. 'Statistik der Berufsüberfüllung, mit besonderer Berücksichtigung der geistigen Berufe' (Statistics of Excess Supply in Professions, with Special Consideration for the Intellectual Professions). Statistisches Archiv 22: 481-91.

CONRAD, J. 1884. 'Das Universitätsstudium in Deutschland während der letzten 50 Jahre' (University Studies in Germany during the last 50 Years). Jena.

GUNKEL, K. 1911. Zweihundert Jahre Rechtsleben in Hannover (The Bicentenary of Law in Hanover). Hanover.

HADRICH, J. 1931. 'Der Hartmannbund im Kampf gegen die Überfüllung der Hochschulen' (The Hartmann Union in the Fight against Excess Supply in Higher Education'). Arztliche Mitleilungen $34:$ 484-87.

HERRMANN, U. ed. 1977. Schule und Gesellschaft im 19. Jahrhundert (School and Society in the 19th Century). Weinheim: Beltz. 


\section{HARTMUT TITZE}

HERRLITZ, H.-G. 1973. Studium als Standesprivileg (Academic Study as Status Privilege). Frankfurt/Main: Fischer.

HERRLITZ, H.-G. and TITZE, H. 1976. 'Überfüllung as bildungspolitische Strategie. Zur administrativen Steuerung der Lehrerarbeitlosigkeit in Preussen 1870-1914' (Excess Supply as a Strategy in Educational Policy. The Administrative Control of Teachers' Unemployment in Prussia 1870-1914). Die Deutsche Schule 68 : 348-70.

HERRLITZ, H.-G. et al 1981. Deutsche Schulgeschichte von 1800 bis zur Gegenwart (The German History of Education from 1800 until the Present). Königstein/Ts.: Athenäum.

HILLIG, J. 1964. 'Lehrerbestand und Lehrernachwuchs der Gymnasien in der Bundesrepublik' (The Supply of Teachers and the New Teaching Generation at the Grammar Schools of the Federal Republic of Germany). Dissertation. Cologne.

HOFFMANN, J.G. 1843. Sammlung kleiner Schriften staatswirthschaftlichen Inhalts (Collection of Essays on the National Economy). Berlin.

HOPF, W. 1984. 'Bildung und Reproduktion der Sozialstruktur' (Education and the Reproduction of the Social Structure). Enzyklopädie Erziehungswissenschaft 5 : 189-205. Stuttgart: Klett-Cotta.

JARAUSCH, K.H. 1981. 'Die neuhumanistische Universität und die bürgerliche Gesellschaft 1800-1870' (The New Humanist University and Bourgeois Society 1800-1870), in Probst, C. (ed.), Darstellungen und Quellen zur Geschichte der deutschen Einheitsbewegung, Vol. 11 (Depictions and Sources on the History of the German Unification Movement). Heidelberg. pp.11-67.

JARAUSCH, K.H. 1982. Students, Society and Politics in Imperial Germany. Princeton: Princeton University Press.

JEISMANN, K.-E. 1974. Das preussische Gymnasium in Staat und Gesellschaft (The Prussian Grammar School in the State and Society). Stuttgart: Klett.

KAELBLE, H. 1976. 'Sozialer Aufstieg in Deutschland 1850-1914' (Social Upward Mobility in Germany 1850-1914), in Jarausch, K.H. (ed.), Quantifizierung in der Geschichtswissenschaft (Quantification in the Historical Sciences). Dusseldorf, pp.279-304.

KAELBLE, H. 1983. Soziale Mobilität und Chancengleichheit im 19. und 20. Jahrhundert (Social Mobility and Equal Opportunity in the 19th and 20th Centuries). Göttingen: Vandenhoeck und Ruprecht.

KEISER, G. 1932. 'Zum Problem der Überfüllung der akademischen Berufe' (The Problem of Excess Supply in Graduate Professions). Soziale Praxis 41 : 1588-95, 1609-15.

KRAMER, H.J. 1964. Der Lehrermangel am Gymnasium (The Shortage of Teachers at the Grammar School). Weinheim: Beltz.

LUNDGREEN, P. 1981. 'Bildungsnachfrage und differentielles Bildungsverhalten in Deutschland 1875-1975' (The Demand for Education and the Differential Educational Behaviour in Germany 1875-1975), in Kellenbenz, H. (ed.), Wachtstumsschwankungen (Fluctuations in Growth). Stuttgart: Klett-Cotta, pp.61-119.

MOHL, R. 1841. 'Ubber Staatsdienstprüfungen' (Examinations for Civil Servants). Deutsche Vierteljahrs Schrift 4 : 79-103.

MOHL, R. 1845. 'Uber eine Anstalt zur Bildung höherer Staatsdiener' (The Institution for the Education of Higher Civil Servants). Zeitschrift für die gesamte Staatswissenschaft 2 : 268-93.

MÜLLER, D.K. 1977. Sozialstruktur und Schulsystem (Social Structure and the School System). Göttingen: Vandenhoeck und Ruprecht.

NATH, A. 1981. 'Der Studienassessor im Dritten Reich. Eine sozialhistorische Studie zur 'Uberfüllungskrise' des höheren Lehramts in Preussen 1932-1942' (The Graduate Teacher in the Third Reich. A Socio-historical Study of the 'Crisis of Excess Supply' in the Prussian Teaching Profession in Higher Education 1932-1942). Zeitschrift für Pädagogik 27 : 281-306.

NIESSEN, L. 1931. Der Lebensraum der geistigen Arbeiter (The Living Space of Intellectual Workers). Münster.

RAMDOHR, F.W.B. von 1801. Über die Organisation des Advocatenstandes (The Organisation of the Legal Profession). Hanover.

RINGER, F. 1979. Education and Society in Modern Europe. Bloomington: Indiana University Press.

ROMBERG, H. 1979. Staat und höhere Schule (The State and the Higher School). Weinheim: Beltz. 


\section{THE CYCLICAL OVERPRODUCTION OF GRADUATES IN GERMANY}

SCHAIRER, R. 1932. Die akademische Berufsnot (The Problem of Graduate Professions). Jena: Diederichs.

SCHMIDT, K.-D. 1982. Zum Problem der Lehrerarbeitslosigkeit (The Problem of Teachers' Unemployment). Kiel.

SIKORSKI, H. 1932. 'Die Überfüllung der Hochschule und akademischen Berufe' (The Overcrowding of the University and the Graduate Professions). Der Arbeitgeber : 53-56.

TITZE, H. 1977. 'Die soziale und geistige Umbildung des preussischen Oberlehrerstandes von 1870 bis 1914' (The Social and Intellectual Reorganisation of the Prussian Secondary School Teaching Profession from 1870 to 1914). Zeitschrift für Pädagogik 14 (Supplement) : 107-28.

TITZE, H. 1981a. 'Überfüllungskrisen in akademischen Karrieren: eine Zyklustheorie' (Crises of Excess Supply in Graduate Careers: a cyclical theory'). Zeitschrift für Pädagogik 27: 187-224.

TITZE, H. 1981b. 'Lehramtsüberfüllung und Lehrerauslese im Obrigkeitsstaat. Zur Steuerung des Lehrernachwuchses im Königreich Hannover 1830-1865' (The Excess Supply in the Teaching Profession and the Selection of Teachers in the Authoritarian State. On the Control of the New Teaching Generation in the Kingdom of Hanover 1830-1865). Die Deutsche Schule $73: 19-30$.

TITZE, H., NATH, A. and MÜLLER-BENEDICT, V. 1985. 'Der Lehrerzyklus. Zur Wiederkehr von Überfüllung und Mangel im höheren Lehramt in Preussen' (On the Supply and Demand Cycle in the Teaching Profession in Prussian Secondary Schools). Zeitschrift für Pädagogie 31 : 97-126.

TITZE, H. 1987 (in collaboration with Herrlitz, H.-G., Müller-Benedict and Nath, A.). Datenhandbuch zur deutschen Bildungsgeschichte. Band 1: Hochschulen. 1. Teil. Das Hochschulstudium in Preussen und Deutschland 1820-1944 (Data Handbook on the German History of Education. Vol. 1.). Göttingen: Vandenhoeck und Ruprecht.

TROSCHKE, P. 1931. Evangelische Kirchenstatistik Deutschlands, Vol. 6/7. Berlin

ZÄNKER, D. 1933. Akademikertum in der Krise (Graduates in Crisis). Wolfratshausen.

ZYMEK, B. 1981. 'Der verdeckte Strukturwandel im höheren Knabenschulwesen Preussens zwischen 1920 und 1940' (The Concealed Structural Change in the Prussian Boys' School System between 1920 and 1940). Zeitschrift für Pädagogik $27: 271-80$.

ZYMEK, B. 1982. 'Expansion und Differenzierung, Perspektive und Enttäuschung. Strukturwandel und Qualifikationskrisen im höheren Schulwesen Preussens während der ersten Hälfte des 20. Jahrhunderts' (Expansion and Differentiation, Structural Change and Crises in the Prussian Qualification System during the First Half of the 20th Century). Postdoctoral Thesis. Bochum.

\section{References: Documents}

1828. Über die Mängel des höheren Unterrichtswesen, besonders im Königreich Hannover (The Shortcomings of the Higher Education System, with particular reference to the Kingdom of Hanover). Hamburg.

Central State Archive of the GDR, Dienststelle Merseburg (ZStA Merseburg), Rep. 92, Nachlass Althoff, A I, No. 92: Normalbedarf der Studierenden; Nr. 100: Gelehrtes Proletariat.

University Archive, Göttingen. Akten der Theologischen Fakultät, No. 112: Die theologischen Prüfungsordnungen 1831-1885; No. 128: Ephoratsberichte 1800-1863.

Biographical Note: Hartmut Titze (Ph.D. Phil.) was born in 1944 in Breslau (Silesia). He gained his doctorate in 1972 at Frankfurt/Main University with a thesis published as Die Politisierung der Erziehung in 1973. In 1985 he was appointed as Professor at the Pädagogisches Seminar of the University of Göttingen. Main research interest: the history of education.

Address: Pädagogisches Seminar der Universität, Hainholzweg 32, 3400 Göttingen, FRG. 